\title{
Epidemiologic Analysis of Gastric Carcinoma in the Western Region of Nepal
}

\author{
Ghosh $\mathrm{A}^{1}$, Sathian $\mathrm{B}^{2}$, Gharti D M${ }^{3}$, Narasimhan $\mathrm{R}^{4}$, Talwar $0 \mathrm{P}^{5}$
}

${ }^{1}$ Associate Professor, Department of Pathology, Manipal College of Medical Sciences, Pokhara, Nepal

${ }^{2}$ Assistant Professor, Department of Community Medicine, Manipal College of Medical Sciences, Pokhara, Nepal

${ }^{3}$ Lecturer, Department of Pathology, Manipal College of Medical Sciences, Pokhara, Nepal

${ }^{4}$ Professor, Department of Pathology, Manipal College of Medical Sciences, Pokhara, Nepal

${ }^{5}$ Professor \& HOD, Department of Pathology, Manipal College of Medical Sciences, Pokhara, Nepal

\section{Original Article}

\section{Corresponding Author:}

Dr. Arnab Ghosh, Associate Professor, Department of Pathology, Manipal College of Medical Sciences, Pokhara, Nepal.

Email:drghosharnab@yahoo.com

\section{Abstract}

\section{Background}

Gastric cancer is among the most common malignancies in Asia, comprising $74 \%$ of all global cases. Identifying the environmental risk factors may possibly shed more light on effective treatment and the prevention of this disease. The aim of our study is to document different histologic types of gastric cancer as per age, sex and ethnic groups in the patients in Nepal, to know the frequency of different gross and microscopic subtypes (according to Lauren's classification) of tumor and to find out the association of $\mathrm{H}$. pylori and other major risk factors with gastric cancer.

\section{Materials and Methods}

The present study is a hospital based retrospective study done in the Department of Pathology, Manipal Teaching Hospital, Pokhara, Nepal, from Jan 1999 to July 2010. All the endoscopic biopsies and gastrectomy specimens from patients with diagnosed gastric carcinoma were reviewed and the clinical and other data were analyzed.

\section{Results}

In this study period, a total of 1223 cases related to stomach were received in Department of Pathology. Considering the inclusion and exclusion criteria, a total of 397 cases - 315 cases of endoscopic biopsy and 82 cases of gastrectomy were included in the study. In our study, the most affected age group and caste were $61-70$ years $(47.36 \%, \mathrm{Cl} 42.44 \%$ to $52.27 \%$ ) and Gurungs ( $32 \%, \mathrm{Cl} 27.16 \%$ to $36.32 \%$ ). The commonest gross and microscopic types were Borrmann's type IV (40\%, Cl $29.63 \%$ to $50.86 \%)$ and intestinal type (53\%, $\mathrm{Cl} 47.99 \%$ to $57.81 \%)$. Gastric antrum was the most affected site $(70 \%, \mathrm{Cl} 65.26 \%$ to $74.29 \%)$. Among the cases with $\mathrm{H}$ pylori, antrum (62.5\% Cl $45.73 \%$ to $79.27 \%$ ) was found to be the commonest site. Among all cases in Gurung, Chhetri and Brahmin communities, we retrieved data regarding risk factors in 93, 65 and 50 cases respectively. Significant relationship was found between the three risk factors studied and the ethnic groups. Smoked meat and alcohol were found to be associated with gastric carcinoma more in Gurungs and Chhetris than in Brahmins $(p=0.0001)$. On the contrary, cases among Brahmins are found to more associated with smoking than Gurungs and Chhetris ( $p=$ 0.0001).

\section{Conclusion}

Gastric carcinoma is a common malignancy in this part of world. The most high risk group includes elderly males with history of alcoholism and smoked meat consumption in Gurung community and with history of smoking from Brahmin family. We advise that regular endoscopic surveillance should be done at least in high risk group for the early detection of cancer.

\section{Key Words}

Gastric Carcinoma, Ethnicity, Risk Factors, Epidemiology, Helicobacter pylori, Nepal 


\section{Background}

Gastrointestinal cancers account for a large fraction of human neoplasms. They are almost without exception incurable when gross metastases exist ${ }^{1}$. Gastric carcinoma is a worldwide disease. In 1990, it was the second most common cancer in the world with an estimated 800,000 new cases every year, $60 \%$ of them being in developing countries $^{2}$. The areas of highest incidence include Eastern Asia, South America and Eastern Europe and those of lower incidence include North America, North Europe, most parts of Africa and South Eastern Asia ${ }^{3,4}$. However, there has been a steady decline in its incidence and mortality over the past several decades ${ }^{3}$. Its incidence has markedly decreased in developed countries but remains high in countries like Japan and Chile; Japan having the highest incidence worldwide ${ }^{3,5}$. In 2008, it has come down to become the $6^{\text {th }}$ commonest cancer worldwide (Age Standardized Rate $(A S R)=14.1 \%)$ with an estimated $1,000,000$ cases $^{6}$. It is the 4 th commonest cancer in males and 5 th in females. Interestingly, $74 \%$ of all global cases are from Asia, where gastric carcinoma is the $3^{\text {rd }}$ commonest cancer (ASR 18.5\%) including both genders, the 2nd commonest cancer in males and the $4^{\text {th }}$ in females ${ }^{6}$.

The exact cancer prevalence rate in Nepal is unknown due to the lack of a population based national cancer registry. However, every year at least 17,000 new cancer cases are estimated and the figure is expected to go up considerably in the future ${ }^{7}$. According to the present data from Nepal, it is the $5^{\text {th }}$ commonest cancer (ASR 8.2\%) including both genders, 3 rd in males and 6 th in females ${ }^{6}$.

A hospital based study done in Nepal showed that $8.8 \%$ of all cancers treated by radiotherapy in Pokhara were GIT malignancies ${ }^{8}$. Endoscopic biopsy is widely regarded as the most sensitive and specific diagnostic tool for gastric cancer $^{3}$. Neoplasms of various parts of the gastrointestinal tract have a marked variation of distribution. These variations are according to race, gender, age, the part of the gastrointestinal tract affected, geographical region of the world and other exogenous risk factors ${ }^{9,10}$. Identifying the environmental risk factors may possibly shed more light on effective treatment and the prevention of these diseases. The aim of our study was to document different histologic types of gastric cancer as per age, sex and ethnic groups in the patients, to know the frequency of different gross and microscopic subtypes (according to Lauren's classification ) of tumor and to find out the association of $\mathrm{H}$. pylori and other major risk factors with gastric cancer.

\section{Materials and Methods}

The present study is a hospital based retrospective study done in the Department of Pathology, Manipal Teaching Hospital, Pokhara, Nepal in a period from Jan 1999 to July 2010. All the endoscopic biopsies and gastrectomy specimens in patients with diagnosed gastric carcinoma were reviewed and analyzed. Patients' data were retrieved from the records of the Department of Pathology and also Department of Medical Records, Manipal Teaching Hospital. The parameters analyzed were age, gender, ethnicity, risk factors, gross and microscopic types. For gross morphological types, Borrmann classification was followed (Fig 1). All biopsy tissues were fixed in $10 \%$ formalin, processed routinely and stained in Hematoxylin \& Eosin and Giemsa stain for $\mathrm{H}$. pylori.

Cases excluded from the study were (a) tumors with extensive areas of necrosis and no viable or normal looking tissues (b) cases where the site of biopsy is unclear, not mentioned by endoscopist or could not be identified histologically (c) other types of gastric malignancies ( e.g., lymphoma, gastrointestinal stromal tumor etc).

The data collected was analyzed using Excel 2003, R 2.8.0 Statistical Package for the Social Sciences (SPSS) for Windows Version 16.0 (SPSS Inc; Chicago, IL, USA) and EPI Info 3.5.1 Windows Version. Chi- square test and Z-test was used to compare the significance difference or relationship between two variables. A p-value of $<0.05$ (two-tailed) was used to establish statistical significance.

Fig 1: Borrmann Classification - schematic representation ${ }^{3}$
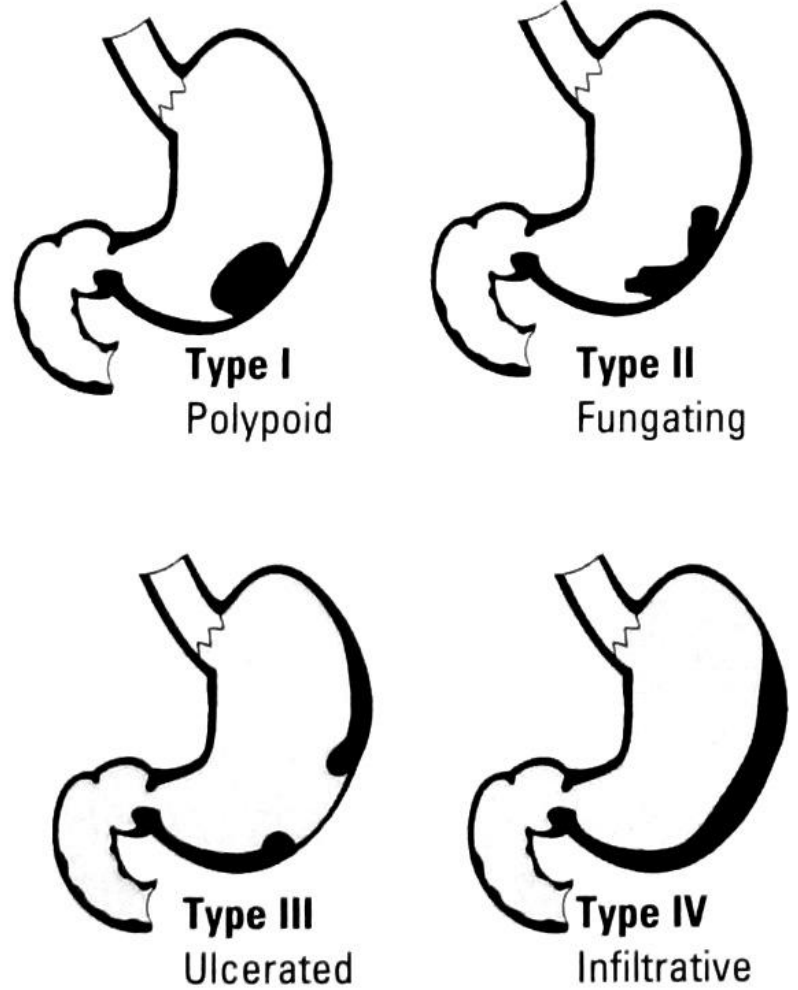

Results

In this study period, a total number of approximately 25000 biopsies have been received in the Department of Pathology. Among these, there were a total of 1223 cases related to stomach (Table 1). Majority of endoscopic biopsies were found to be nonmalignant while all of gastrectomy specimens were found to be malignant. Considering the inclusion and exclusion criteria, a total of 397 cases, including 315 cases of endoscopic biopsy and 82 cases of gastrectomy were included in the study. 
Epidemiologic Analysis of Gastric Carcinoma in the Western Region of Nepal

Table 1: Frequency of endoscopic biopsy and gastrectomy cases

\begin{tabular}{|l|c|c|c|}
\hline $\begin{array}{l}\text { Frequency of } \\
\text { Cases }\end{array}$ & $\begin{array}{c}\text { Endoscopic } \\
\text { biopsy }\end{array}$ & $\begin{array}{c}\text { Gastrectomy } \\
\text { specimen }\end{array}$ & Total \\
\hline $\begin{array}{l}\text { Total cases } \\
\text { Malignant } \\
\text { cases } \\
\text { Included } \\
\text { in the study }\end{array}$ & 340 & 86 & 1223 \\
\hline
\end{tabular}

Table 2 shows age wise frequency of all the studied cases. There is a sharp increase in incidence after 50 years of age and highest number is seen in the age group 51-70 years. Males are more commonly affected than females in a $M: F$ ratio of 1.8:1 (Table 3) .

Table 2: Distribution of cases according to age

\begin{tabular}{|c|c|c|c|}
\hline $\begin{array}{c}\text { Age } \\
\text { range }\end{array}$ & $\begin{array}{c}\text { Number of } \\
\text { cases }\end{array}$ & Percentage & Cl \\
\hline $\mathbf{2 1 - 3 0}$ & 5 & 1.26 & $\mathbf{( 0 . 1 6 , 2 . 3 6 )}$ \\
$\mathbf{3 1 - 4 0}$ & 9 & 2.27 & $\mathbf{( 0 . 8 , 3 . 7 3 )}$ \\
$\mathbf{4 1 - 5 0}$ & 19 & 4.79 & $\mathbf{( 2 . 6 7 , 6 . 8 9 )}$ \\
\hline $\mathbf{5 1 - 6 0}$ & 143 & 36 & $\mathbf{( 3 1 . 3 , 4 0 . 7 4 )}$ \\
$\mathbf{6 1 - 7 0}$ & 188 & 47.36 & $\mathbf{( 4 2 . 4 4 , 5 2 . 2 7 )}$ \\
$\mathbf{7 1 +}$ & 33 & 8.31 & $\mathbf{( 5 . 6 , 1 1 . 0 3 )}$ \\
\hline Total & 397 & & \\
\hline
\end{tabular}

Table 3: Distribution of cases according to gender

\begin{tabular}{|c|c|c|c|c|}
\hline Gender & $\begin{array}{c}\text { Number of } \\
\text { cases }\end{array}$ & Percentage & Ratio & p value \\
\hline Male & 254 & 64 & 1.8 & 0.001** \\
\hline Female & 143 & 36 & 1.0 & \\
\hline Total & 397 & & & \\
\hline
\end{tabular}

** Statistically significant ( $p$ value $<0.05$ )

Among the different castes, Gurungs are much more commonly affected with $32 \%$ of all cases (Table 4 ). They are closely followed by Chhetri and Brahmins comprising $21 \%$ and $15 \%$ respectively.

Table 4: Distribution of cases according to caste

\begin{tabular}{|c|c|c|c|}
\hline Caste & $\begin{array}{c}\text { Number } \\
\text { of cases }\end{array}$ & Percentage & $\mathbf{C l}$ \\
\hline Gurung & 126 & 32 & $\mathbf{( 2 7 . 1 6 , 3 6 . 3 2 )}$ \\
\hline Chhetri & 83 & 21 & $\mathbf{( 1 6 . 9 1 , 2 4 . 9 1 )}$ \\
Brahmin & 60 & 15 & $\mathbf{( 1 1 . 5 9 , \mathbf { 1 8 . 6 4 ) }}$ \\
Magar & 29 & 7 & $(\mathbf{4 . 7 5}, \mathbf{9 . 8 6 )}$ \\
Newar & 28 & 7 & $\mathbf{( 4 . 5 3 , 9 . 5 7 )}$ \\
Other castes & 71 & 18 & $\mathbf{( 1 4 . 1 1 , 2 1 . 6 5 )}$ \\
\hline Total & 397 & & \\
\hline
\end{tabular}

Table 5: Site wise distribution of all cases included in the study

\begin{tabular}{|c|c|c|c|}
\hline Site & $\begin{array}{c}\text { Number of } \\
\text { cases }\end{array}$ & Percentage & $\mathbf{C l}$ \\
\hline Antrum & 277 & 70 & $(\mathbf{6 5 . 2 6 , 7 4 . 2 9 )}$ \\
\hline Corpus & 78 & 20 & $(\mathbf{1 5 . 7 4 , 2 3 . 5 6 )}$ \\
\hline Fundus & 28 & 7 & $(\mathbf{4 . 5 3 , 9 . 5 7 )}$ \\
\hline Cardia & 14 & 3 & $\mathbf{( 1 . 7 1 , 5 . 3 4 )}$ \\
\hline Total & 397 & & \\
\hline
\end{tabular}

Antrum was found to be the site of carcinoma in $70 \%$ of cases, thus being the most common site (Table 5). Gross morphologic types were studied in all 82 gastrectomy cases (Table 6) according to Borrmann's type. Type IV was the commonest type with 33 cases (40\% of all 82 cases). Microscopically, all cases were divided as per Lauren's classification and it was found that 210 cases (53\%) were of intestinal type (Table 7).

Table 6: Gross morphological distribution of all gastrectomy cases

\begin{tabular}{|c|c|c|c|c|}
\hline $\begin{array}{c}\text { Bormann's Gross types } \\
\text { and Descriptions }\end{array}$ & $\begin{array}{c}\text { Number } \\
\text { of cases }\end{array}$ & $\%$ & Cl \\
\hline $\begin{array}{c}\text { Type } \\
\text { I }\end{array} \begin{array}{c}\text { Polypoid } \\
\text { protruding } \\
\text { growth. } \\
\text { II }\end{array}$ & $\begin{array}{c}\text { Fungating growth. } \\
\text { with discrete } \\
\text { sharply defined } \\
\text { borders }\end{array}$ & 22 & 27 & (17.24, 36.42) \\
\hline $\begin{array}{c}\text { Type } \\
\text { III }\end{array}$ & $\begin{array}{c}\text { Ulcerated and } \\
\text { infiltrating with no } \\
\text { discrete borders in } \\
\text { ulcer }\end{array}$ & 27 & 33 & $\mathbf{( 2 2 . 7 6 , 4 3 . 1 0 )}$ \\
\hline $\begin{array}{c}\text { Type } \\
\text { IV }\end{array}$ & $\begin{array}{c}\text { Diffuse infiltrating, } \\
\text { linitis plastica } \\
\text { Total }\end{array}$ & 33 & 40 & $\mathbf{( 2 9 . 6 3 , 5 0 . 8 6 )}$ \\
\hline
\end{tabular}

Table 7: Microscopic types - distribution of all cases included in the study

\begin{tabular}{c|c|c|c|}
$\begin{array}{c}\text { Microscopic } \\
\text { types ( Lauren's } \\
\text { classification ) }\end{array}$ & $\begin{array}{c}\text { Number } \\
\text { of cases }\end{array}$ & $\begin{array}{c}\text { Percentage } \\
\text { (n= 82) }\end{array}$ & Cl \\
\hline $\begin{array}{c}\text { Intestinal } \\
\text { Diffuse }\end{array}$ & 210 & 53 & $\mathbf{( 4 7 . 9 9 , \mathbf { 5 7 . 8 1 ) }}$ \\
Mixed type & 123 & 31 & $\mathbf{( 2 6 . 4 3 , 3 5 . 5 3 )}$ \\
Total & 64 & 16 & $\mathbf{( 1 2 . 5 0 , 1 9 . 7 4 )}$ \\
\hline
\end{tabular}

H. pylori was associated with 32 cases i.e. $8 \%$ of all carcinoma cases (Table 8). 
Table 8: Association of $\mathrm{H}$ pylori and its relation to site of carcinoma

\section{H. Pylori association with cancer ( $N=32,8 \%$ of total cases)}

\begin{tabular}{|c|c|c|c|}
\hline $\begin{array}{c}\text { Site of } \\
\text { carcinoma }\end{array}$ & $\begin{array}{c}\text { Number } \\
\text { of cases }\end{array}$ & Percentage & Cl \\
\hline Antrum & 20 & 62.5 & $\mathbf{( 4 5 . 7 3 , 7 9 . 2 7 )}$ \\
\hline Corpus & 11 & 34.4 & $\mathbf{( 1 7 . 9 2 , 5 0 . 8 3 )}$ \\
\hline Cardia & 1 & 3.1 & $\mathbf{( 0 , 9 . 1 5 )}$ \\
Fundus & 0 & 0 & -- \\
\hline Total & $\mathbf{3 2}$ & & \\
\hline
\end{tabular}

Table 9: Caste-wise Assessment of major risk factors

\begin{tabular}{|c|c|c|c|c|c|}
\hline & & Gurung & Chhetri & Brahmin & $p$ value \\
\hline Total case & & 126 & 83 & 60 & \\
\hline $\begin{array}{l}\text { Data ava } \\
\text { for risk fa }\end{array}$ & $\begin{array}{l}\text { lable } \\
\text { tor }\end{array}$ & 93 & 65 & 50 & \\
\hline Smoked & Yes & 68 & 41 & 18 & $0.0001 * *$ \\
\hline meat & No & 25 & 24 & 32 & \\
\hline Alcohol & Yes & 72 & 39 & 19 & $0.0001 * *$ \\
\hline & No & 21 & 26 & 31 & \\
\hline Smoking & Yes & 32 & 25 & 36 & $0.0001 * *$ \\
\hline & No & 61 & 40 & 14 & \\
\hline
\end{tabular}

** Statistically significant ( $p$ value $<0.05$ )

Among all cases in Gurung, Chhetri and Brahmin communities, we could retrieve data on risk factors in 93, 65 and 50 cases respectively. Significant relationship was found between the three risk factors studied and ethnic groups (Table 9). Smoked meat was found to be associated with gastric carcinoma in Gurungs, Chhetris and Brahmins in $73 \%, 63 \%$, and $36 \%$ cases respectively. Similarly alcohol consumption was found to be associated more commonly with Gurungs (77\%) and Chhetris (60\%) than among Brahmins (38\%). On the contrary, cases among Brahmins (72\%) are found to more associated with smoking than Gurungs (34\%) and Chhetris (38\%).

\section{Discussion}

Gastric carcinoma is one of the most common malignancies worldwide and is among the top five malignancies encountered at Manipal Teaching Hospital ${ }^{8}$. Among all the histopathological tissues received in the Department of Pathology, approximately $5 \%$ cases were related to gastric pathology. We have reported a total of 426 cases of gastric malignancy ( $1.7 \%$ of all cases and $35 \%$ of all gastric tissue) in the study period. As per our exclusion criteria, 397 cases were included in the study.

Gastric carcinoma is extremely rare before the age of 30 years and most patients are above 50 years of age a $^{3,5}$. Though a steady decline in the incidence and mortality rates of gastric carcinoma has been observed worldwide over the past several decades, the absolute number of new cases per year is increasing mainly because of the aging of the population $^{11}$. In our study, majority of the patients (331 cases, $83 \%$ ) were in the age range of 51 to 70 years. This finding corroborates well with international trends. However, cases of gastric carcinoma in young and even in children are recorded in world literature and we found 5 cases in the age group of 21-30 years ${ }^{12,13}$. As seen in other international studies, males are clearly affected more commonly, nearly two times more than females in our data ${ }^{3}$.

All gastric carcinomas arise from foveolae; in most instances, in a back ground of chronic atrophic gastritis with intestinal metaplasia ${ }^{14,15}$. The most frequent site of stomach cancer is the distal stomach i.e., the antro-pyloric region ${ }^{3}$. Carcinomas of the body or the corpus are located mostly along the greater or lesser curvature ${ }^{3,5}$. In our study, the distal stomach (antrum) was also seen to be the primary site in $70 \%$ of cases followed by the body or corpus (20\%).

Grossly, gastric carcinomas show a wide variation ${ }^{5}$. Dysplasias may present as a flat lesion, difficult to detect on conventional endoscopy ${ }^{3}$. The gross appearances of advanced carcinoma include flat, ulcerated, or fungating tumor growing into the gastric lumen and deeply invasive tumor growing through the wall of the stomach ${ }^{5,16}$. Borrmann classified the gross appearance of advanced carcinomas into 4 types based on the proportion of exophytic and endophytic components ${ }^{3,5,17}$. Fig. 1 shows the schematic representation of four gross morphological types described by Borrmann ${ }^{3}$. Types II and III are common ${ }^{3}$. Diffuse type (Type IV) spread superficially in the mucosa and submucosa producing flat lesions with or without ulceration. With extensive infiltration, a linitis plastica or leather bottle stomach results. In our study, we analyzed 82 gastrectomy cases. We found type IV (diffuse infiltrating) to be the most common constituting $40 \%$ of 82 cases. However, combined type II and III comprise 60\%. We did not find any nonulcerated polypoid type (type I) in our study. Type IV has been found to be an independent prognostic factor by other studies ${ }^{18}$. More studies from this country on this aspect are invited. Depending of the relative proportion of mucin and fibrosis, the tumor may have fleshy, fibrous or gelatinous appearance ${ }^{3,5}$.

Microscopically, this carcinoma has been divided into two major categories by Lauren in $1965^{19}$. Lauren classification has been found useful in evaluating the natural history of gastric carcinoma ${ }^{3}$. According to Lauren Classification, the main two types are "intestinal" and "diffuse" type. Tumors that contain approximately equal quantities of both components are called "mixed" type and carcinomas too undifferentiated to fit into any category are placed in "indeterminate" type ${ }^{3}$. Intestinal carcinomas form recognizable glands ranging from poorly to moderately differentiated and well differentiated. On the other hand, diffuse type consists of poorly cohesive cells diffusely infiltrating the gastric wall with minimal gland formation ${ }^{3,5}$. This type is currently known as "signet ring" carcinoma as most of the cells contain intracytoplasmic mucin giving the cell the typical signet ring appearance ${ }^{3,5}$. According to the original study by Lauren, intestinal type comprised $53 \%$ and 
diffuse type comprised $33 \%$. In our study, the findings are closely similar with intestinal type being $53 \%$ and diffuse type $31 \%$.

$\mathrm{H}$. pylori has been implicated as an etiologic factor in gastric carcinoma through development of chronic gastritis ${ }^{20}$. Strong evidence has been shown in prospective cohort studies that presence of $\mathrm{H}$. pylori antibodies in serum poses a significant increased risk of carcinoma ${ }^{21}$. H. pylori causes these sequential stages of disease progression - chronic gastritis, multifocal atrophy, intestinal metaplasia and intraepithelial neoplasia. Gastritis and atrophy lead to elevated $\mathrm{pH}$ altering the colonizing bacterial flora. These bacteria activate reductases that form nitrite from food nitrate. This nitrite reacts with amines, amides and ureas producing carcinogenic $\mathrm{N}$-nitroso compounds ${ }^{22,23}$. H. pylori however are mainly seen in normal mucosa and are absent in areas with intestinal metaplasia where neoplasia originates ${ }^{3}$. In our study, we searched for $\mathrm{H}$. pylori in both the neoplastic and non-neoplastic mucosa in all 397 malignant cases. We found presence of $\mathrm{H}$. pylori only in 32 cases $(8 \%)$. However, it is premature to come to any conclusion and there is scope of further study to assess the association of $\mathrm{H}$. pylori with gastric carcinoma in this part of the world. A follow-up meta-analysis of 42 studies carried out by Eslick GD et al showed a significant relationship between $H$. pylori and gastric cancer ${ }^{24}$. Several studies reported that $\mathrm{H}$. pylori infection for 10 or more years poses a significantly increased risk for carcinoma ${ }^{25}$. So, ideally, cases with $\mathrm{H}$. pylori associated gastritis should be prospectively followed up for adequate period to correctly assess its association with carcinogenesis. Several studies have been done regarding prevalence of genetic strains of $H$. pylori in different ethnic groups. As it was found that $H$. pylori has evolved together with its host, the subpopulation of $\mathrm{H}$. pylori serves as a surrogate marker for estimating anthropological and demographic migrations. Manjulata Devi $S$ et al have shown in their study that the important $H$. pylori strains prevalent in India share more ancestral similarity with their European counterparts rather than African and East Asian strains ${ }^{26}$. Farhana $\mathrm{K}$ et al has studied the genetics of $\mathrm{H}$. pylori strain in high altitude low populated Himalayan terrain like Ladakh and found it to be distinct and less virulent than the strains in East Asian countries like China and Japan ${ }^{27}$. Shalome $C$ et al also has found in their study among different ethnic groups in New Zealand that there are ethnic group specific $H$. pylori strains $^{28}$. Western Nepal being geographically located in sub-Himalayan terrain may show presence of some unique $\mathrm{H}$. pylori strains reflecting its geo-climatic and anthropological nature. Studies have also been carried out with respect to responsiveness and resistance of different strains of $\mathrm{H}$. pylori to different medication regimens.

Among other risk factors, the most consistent association is diet. This is especially true for intestinal carcinoma ${ }^{3}$. Salt intake, smoked meat, smoked fish, pickled vegetables, chili peppers, alcohol and tobacco are found to incur high risk ${ }^{3,}$ 29. In our study, we classified the incidence of gastric carcinoma in different castes and also tried to find out the importance of smoked meat, alcohol and smoking as risk factors. According to an estimation by the World Health Organization (WHO), $38.4 \%$ of the total population of Nepal above 15 years of age smoke, of which $48.4 \%$ are males and $28.7 \%$ are females ${ }^{30}$. NY Sung et al had carried out a prospective study in Korean population and found strong association of smoking and alcohol consumption with gastric carcinoma. He further states than combined smoking and alcohol poses a higher risk as synergistic effect ${ }^{31}$.

Despite a high incidence in many Asian nations, populationbased studies indicate that Asian-American patients have improved gastric cancer survival compared with other races and ethnicities ${ }^{32-35}$. However, the categorization of Asian ethnicities as a single race appears inappropriate, given that Asians are a culturally diverse mix of people that differ widely in country of origin, immigration patterns, socioeconomic status, and lifestyle factors ${ }^{36-38}$. Nevertheless, epidemiologic studies often aggregate these diverse populations without mention of the specific ethnic subgroups. The flaw in this practice was recently underscored by a report from Kwong et al., who observed wide variations in cancer incidence and mortality among the five most prevalent Asian-American subgroups, namely Korean, Japanese, Chinese, Vietnamese, and Filipino ${ }^{39}$. These observations highlight the need to carefully examine gastric cancer outcomes among the different Asian ethnicities. In Nepal, we found that Gurungs are more commonly affected followed by Chhetris and Brahmins comprising $32 \%, 21 \%$ and $15 \%$ respectively.

\section{Conclusion}

Gastric carcinoma is a common malignancy in this part of world. There is need of further follow up cohort studies regarding carcinogenic property of $\mathrm{H}$. pylori and prevalence of its different strains in different ethnic groups in the subHimalayan belt. This may help in understanding the pathogenesis of gastritis and gastric cancer as well as the responsiveness and resistance of different anti-helicobacter regimens. The most high risk group includes elderly males with history of alcoholism \& smoked meat consumption from Gurung community and with history of smoking from Brahmin family. There is obvious scope of further studies on gastric carcinoma in other parts of this country and to also assess the other risk factors in this population. However, we advise that regular endoscopic surveillance should be done at least in the high risk group for the early detection of cancer.

\section{Conflict of Interests}

The authors do not have any conflict of interest arising from the study.

\section{Acknowledgements}

Dr. B M Nagpal, CEO Manipal Education and Medical group \& Dean, Manipal College of Medical Sciences, P O Box No 155, Deep Heights, Pokhara, Nepal for permitting the authors to use the hospital documents during the study. 


\section{References}

1. Rosen N. Cancers of the Gastrointestinal Tract. In: Devita Jr VT, Hellman S, Rosenberg SA, eds. Cancer: Principles \& Practice of Oncology. 5th ed. Philadelphia: Lippincott-Raven Publishers; 1997, 32.1, pp 971-80.

2. Parkin DM, Pisani P, Ferlay J. Estimates of the worldwide incidence of 25 major cancers in 1990. Int J Cancer 1999; 80(6): 827-41.

3. Fenoglio-Preiser C, Carneiro F, Correa P, Guilford P, Lambert R, Megraud F et al. Gastric Carcinoma. In: Hamilton SR, Aaltonen LA, eds. Pathology \& Genetics Tumors of digestive system, Lyon: IARC Press; 2000, pp 39-52.

4. Parkin DM, Whelan SL, Ferlay J, Raymond L, Young J. Cancer incidence in five continents. Lyon, France: IARC Press,1997.

5. Rosai J. Gastrointestinal tract. In: Rosai and Ackerman's surgical pathology. Vol.1. 9 ed. New Delhi: Elsevier, 2004, pp 648-711.

6. Ferlay J, Shin HR, Bray F, Forman D, Mathers C, Parkin DM. GLOBOCAN 2008, Cancer Incidence and Mortality Worldwide: IARC Cancer Base No. 10 [Internet]. Lyon, France: International Agency for Research on Cancer; 2010. Available from: http://globocan.iarc.fr

7. Ferlay J, Bray F, Pisani P, Parkin DM. GLOBOCAN 2002. Cancer Incidence, Mortality and Prevalence Worldwide. IARC Cancer Base No. 5 Version 2.0. Lyon, France: IARC Press, 2004.

8.Sathian B, Bhatt CR, Jayadevan S, Ninan J, Baboo NS, Sandeep G. Prediction of cancer cases for a hospital in Nepal: a statistical modelling. Asian Pac J Cancer Prev 2010;11(2): 441-5.

9.Trichopoulos D, Lipworth L, Petridou E, Adami HO. Epidemiology of Cancer. In: Devita Jr VT, Hellman S, Steven A, eds. Cancer: Principles \& Practice of Oncology. 5th ed. Philadelphia: Lippincott-Raven Publishers, 1997, 235-9.

10.Kumar V, Cotran RS, Robbins SL. Basic Pathology. 6th ed. Singapore: Harcourt Asia Pte. Ltd., 1997, 142.

11.Munoz N. Descriptive epidemiology of stomach cancer. In: Reed PI, Hill MJ, eds. Gastric Carcinogenesis, New York: Excerpta Medica, 1988.

12.Grabiec J , Owen D A .Carcinoma of the stomach in young persons. Cancer $1985 ;$ 56(2):388- 96.

13. Tso PL, Bringaze WL 3rd, Dauterive AH, Correa P, Cohn I Jr. Gastric carcinoma in the young. Cancer 1987;59(7): 1362-5.

14.Taki K, Kuwabara N. Studies on histogenesis of the gastric carcinoma using minute cancers. Pathol Res Pract 1981;172(1-2):176-90.

15. Hattori T. Development of adenocarcinomas in the stomach. Cancer 1986;57(8):1528-34.

16. Correa P. Pathology of gastric cancer. Clin Oncol 1984;3: 251-7.

17. Borrmann R. Geshwulste des Magens und Duodenums. In: Henke F, Lubarsch $O$, eds. Handbuch der Speziellen Pathologischen Anatomie und Histologie. Berlin: SpringerVerlag, 1926.

18. An JY, Kang TH, Choi MG, Noh JH, Sohn T, Kim S. Borrmann Type IV: an independent prognostic factor for survival in gastric cancer. J Gastrointest Surg 2008; 12(8):1364- 9.

19. Lauren P. The Two Histological Main Types of Gastric Carcinoma: Diffuse and So-Called Intestinal-Type Carcinoma. An attempt at a Histo-Clinical Classification. Acta Pathol Microhiol Scand 1965; 64:31-49.

20. P Correa, J Fox and E Fontham et al. Helicobacter pylori and gastric carcinoma. Cancer 1990;66: 2569 -74.

21. Parsonnet J, Friedman GD, Vandersteen DP, Chang $Y$, Vogelman JH, Orentreich N, Sibley RK. Helicobacter pylori infection and the risk of gastric carcinoma. N Engl J Med 1991;325(16):1127-31.

22. Correa P. Human gastric carcinogenesis: a multistep and multifactorial process - First American Cancer Society Award Lecture on Cancer Epidemiology and Prevention. Cancer Res 1992;52(24):6735-40.

23. Yang D, Tannenbaum SR, Buchi G, Lee GC . 4-Chloro-6methoxyindole is the precursor of a potent mutagen (4chloro-6-methoxy-2-hydroxy-1-nitroso-indolin-3-one oxime) that forms during nitrosation of the fava bean (Vicia faba). Carcinogenesis 1984;5(10):1219-24.

24. Eslick GD, Lim LL, Byles JE, Xia HH, Talley NJ. Association of Helicobacter pylori infection with gastric carcinoma: a meta-analysis. Am J Gastroenterol 1999;94(9):2373-9.

25. Dicken BJ, Bigam DL, Cass C, Mackey JR, Joy AA, Hamilton SM. Gastric adenocarcinoma: review and considerations for future directions. Ann Surg 2005;241(1):27-39.

26. Devi SM, Ahmed I, Francalacci P, Hussain MA, Akhter $Y$, Alvi $A$ et al. Ancestral European roots of Helicobacter pylori in India. BMC Genomics 2007;8:184.

27.Kauser F, Hussain MA, Ahmed I, Ahmad N, Habeeb A, Khan $A A$ et al. Comparing genomes of Helicobacter pylori strains from the high-altitude desert of Ladakh, India. J Clin Microbiol. 2005;43(4):1538-45.

28.Campbell S, Fraser A, Holliss B, Schmid J, O'Toole PW. Evidence for ethnic tropism of Helicobacter pylori. Infect Immun 1997;65(9):3708-12.

29.Jossens JV, Geboers J. Nutrition and gastric cancer. Nutr Cancer 1981;2(4):250-61

30.Ghimire GR. Going up in smoke. Kathmandu Univ Med J 2004; 2(3):180-1.

31.Sung NY, Choi KS, Park EC, Park K, Lee SY, Lee AK et al. Smoking, alcohol and gastric cancer risk in Korean men: the National Health Insurance Corporation Study. Br J Cancer. 2007;97(5):700-4.

32. Parkin DM, Bray F, Ferlay J, Pisani P. Global cancer statistics, 2002. CA Cancer J Clin 2005;55(2):74-108.

33. HundahI SA, Phillips JL, Menck HR. The National Cancer Data Base Report on poor survival of U.S. gastric carcinoma patients treated with gastrectomy: Fifth Edition American Joint Committee on Cancer staging, proximal disease, and the "different disease" hypothesis. Cancer 2000;88(4):92132.

34. Theuer CP, Kurosaki T, Ziogas A, Butler J, Anton-Culver $\mathrm{H}$. Asian patients with gastric carcinoma in the United States exhibit unique clinical features and superior overall and cancer specific survival rates. Cancer 2000;89(9):1883-92. 
35. Gill S, Shah A, Le N, Cook EF, Yoshida EM. Asian ethnicity-related differences in gastric cancer presentation and outcome among patients treated at a canadian cancer center. J Clin Oncol 2003;21(11):2070-6.

36. Suwanrungruang $K$, Sriamporn $S$, Wiangnon $S$, Rangsrikajee D, Sookprasert A, Thipsuntornsak N, et al. Lifestyle-related risk factors for stomach cancer in northeast Thailand. Asian Pac J Cancer Prev 2008;9(1):71-5.

37. van Loon AJ, Goldbohm RA, van den Brandt PA. Socioeconomic status and stomach cancer incidence in men: results from The Netherlands Cohort Study. J Epidemiol Community Health 1998;52(3):166-71.

38. Bates JH, Hofer BM, Parikh-Patel A. Cervical cancer incidence, mortality, and survival among Asian subgroups in California, 1990-2004. Cancer 2008;113(10):2955-63.

39. Kwong SL, Chen MS Jr, Snipes KP, Bal DG, Wright WE. Asian subgroups and cancer incidence and mortality rates in California. Cancer 2005;104(12):2975-81. 